\title{
GARS Gene
}

National Cancer Institute

\section{Source}

National Cancer Institute. GARS Gene. NCI Thesaurus. Code C132127.

This gene plays a role in the attachment of glycine to the appropriate tRNA. 